\title{
LIFE CYCLE COST OF BIOMASS POWER PLANT - MONTE CARLO SIMULATION OF INVESTMENT
}

\author{
Petrana Odavić ${ }^{1}$, Vladislav Zekić2 ${ }^{2}$ Dragan Milić ${ }^{3}$
}

\begin{abstract}
Summary
Assessment of life cycle cost is considered as an important instrument for designing and evaluating success of every project. The aim of this work is to determine the precise impact of the investment costs and future operating and maintenance costs of CHP biomass plant. By using the Monte Carlo simulation are determined variations in the settings and the possible impact on the investment risk. The results show that the investment is justified, thanks to the positive outcome of the net present value (NPV), internal rate of return (IRR) and the payback period. The greatest impact on the variability of annual profits have operating costs, which have the highest coefficient of variation of $6.44 \%$ and the largest share. Variability of net present value of $4 \%$ is acceptable, and the investment is considered as stable.
\end{abstract}

Key words: life cycle cost, simulation, variation, discounting.

JEL: Q14, Q21, C53, C61.

\section{Introduction}

Risk and uncertainty are inherent in the economic evaluation of projects and Monte Carlo method has proven to be a powerful alternative in risk assessment. Risk analysis can not guarantee the complete success of the project, but it can be analyzed what are the risks of decision making. Then, while the deterministic methods provide important information about a project, but do not take into account possible changes in the parameters that may affect the realization of the project, probabilistic methods as well as the Monte Carlo method can consider simultaneous variations in several

1 Petrana Odavić M.Sc., Advisor at Provincial secretariat of finance, Government of Vojvodina, Mihajla Pupina Boulevard no. 16, Novi Sad, Serbia, Phone: +381 6039996 69, E-mail: petrana.odavic@gmail.com.

2 Vladislav Zekić Ph.D, Associate Professor, University of Novi Sad, Faculty of Agriculture, Dositeja Obradovića Square no. 8, Novi Sad, Serbia, Phone: +381 2148535 10, E-mail: vladislav.zekic@gmail.com.

3 Dragan Milić Ph.D, Associate Professor, University of Novi Sad, Faculty of Agriculture, Dositeja Obradovića Square no. 8, Novi Sad, Serbia, Phone: +381 2148535 10, E-mail: draganzavod@gmail.com.

EP 2017 (64) 2 (587-599) 
parameters. Those methods can allow easy and fast complete analysis relating to the project sustainability (Yu, Tao, 2008).

To obtain an accurate value for the net present value (NPV), which is used to present information about profit or loss by a simple economic value, other consistent informations are also necessary. NPV is one of the most commonly used indicators in investment analysis. Generally, the information used to calculate the NPV involve some uncertainty. Deterministic methods of stable economies that depend on such data, using a constant value for some indicators, such as interest rates, inflation, prices of used equipment or produced energy prices, without taking into account changes in the informations during the project. For this reason, it is very important to examine and determine the risk of a specific project over time, as it is done in this study through Monte Carlo method.

The investments represent a waiver in the present and spending for the sake of making profit in the future, which is an exchange of something certain for a set of hopes arranged in time. Potential investors must pay special attention to the selection of financing sources depending on their own capabilities. Cash flows are not certain so the investment itself carries certain risks, which is the reason of making Monte Carlo simulation to determine any variations of the investor assessment.

The development of the investment simulation model in $\mathrm{CHP}^{4}$ energy biomass power plant was performed by the method of the total life cycle costs. The formation of possible solutions is based on various input parameters and technology. This approach is of great importance to the quality of potential investors decision-making. In this way, the entire process is covered, i.e. all expenses are defined incurred in the cycle of energy production from renewable sources, from planning and plant construction, development, operations, maintenance and connection to the power grid. The model includes all costs that are considered potentially important in order to estimate the total investment in the long term, and to determine the risk for this type of investment.

\section{Literature review}

Kaufman (1970) has established a methodology to access a method of life cycle costs, which is formulated in eight steps: determining the operational profile, utilization factor, all elements of cost, conversing cost at current prices, escalating inflation, discounting and reducting to the net present value. Based on the initial assumptions of Kaufman's research, life cycle costs of biomass power plant investment are calculated in this paper.

Monte Carlo methods were created in America in the development of thermonuclear weapons at the end of 30's of the last century, and the method name is given by Metropolis (1949), modeled on the town in the principality of Monaco known for its casinos, because of calculation by random numbers and many iterations reminiscent to games of chance. The method, according to the author, in essence is a statistical

4 Combinated Heat and Power 
approach to the study of differential equations or integro-differential equations that appear in the various science branches.

Hertz $(1964,1979)$ found the details of the Monte Carlo method and gave the answer to the question whether there is a way of risk analysis that can help managers to make wise decisions, launch new products, modernize facilities or avoid overcrowding of technical capacities. Mathematical formulas that provide a uniform rate of return is not sufficient. The author emphasizes the nature of the used data and the specific combination of variables such as cash flow, return on investment, which can lead to routine use of risk analysis in everyday business, or in any decision making process.

Harvey (1976) defined in his research simplest procedure of life cycle costs. The author claims that the method enables a complete analysis of all costs, and the compromise between the costs element during the life cycles of assets provides optimum choice.

Barringer and Weber (1996) define a very simple life cycle costs as the sum of the estimate costs from the beginning of a cycle to the removal of equipment or projects by specific analytical study. The goal of the analysis is to determine the most convenient access from a range of alternatives by this method.

Zekić et al. (2014) indicate that in certain areas of research in the social sciences exist significant impact of unpredictable factors and there is no possibility of the experiment, so the use of simulation methods in the study is often imposed as the only possible solution. The basic value on which it is possible to evaluate the simulation model is the quality and usability of the results, because the authors believe that the applied methods and the results should have an optimal relationship between the analytical and application possibilities. In their work, based on the results of Monte Carlo methods, pig production in Serbia expressed a high level of overall business risk which generally lies with the manufacturers.

\section{Data sources and methodology}

Determining the economic efficiency of investments such are the construction and operation of biomass power plants and energy production is very complex, primarily due to the high value of the initial costs and long term nature of business. Recent methods which observe and analyse the costs and success of operations at the level of one production process or a business year, does not provide sufficient accuracy and nreliability. These methods are static methods for the evaluating the investment. Equipment for the production of such energy facilities lasts for many years, and it is possible that the economic effect is often not the same in all years, so it is recommended to discount income of each year on a specific valuation moment and then to make the calculations of economic effects. If it fails to do so, omissions could be done. The methods that take into account the revenues and expenses in different periods of time are called dynamic methods. Within this study is applied a method of net present value, internal rate of return and payback period. The values are obtained through the software MS Excel, formulations NPV, IRR, PMT. 
Monte Carlo method is stochastic (deterministic) method of simulation and respectively represent algorithms that predict the behavior of complex mathematical systems with a random number and a large number of calculation iterations. Probabilistic methods for calculating NPV may contain some parameters that vary over time. In this case, consideration of the uncertainty in the results using this method gives possible information for potential investor decision-making. Monte Carlo method consider that the uncertainty in the behavior of the independent variable, using probability distribution functions in the model, is the way to show the probability in a given situation. In recent decades, this method gets the status of a fully rounded numerical method, capable to solve the most complex demands. It gives a unique balance between the assessment and calculation (Korn et al., 2011).

Due to the existence of multiple independent variables and also dependent variables in the model observed at the same time, there are several parameters for which is needed to determine variability, and then through Monte Carlo method to make a simulation using a computer. Mathematical model emulate the real system of study, in this case it is a complete life cycle of CHP biomass plants for energy generation. The model determines the degree of variation or operational system risk, so that the future investor could easily decide on investment ways. The results obtained by this method must be interpreted objectively and with great caution (Clark et al., 2010).

Input parameters and data for costs evaluation are taken from previous research (Andrews, 2009; Princiotta, 2011; Pedraza, 2015), then from the International Energy Agency (IEA, 2007), US Department of energy (2016), completed projects ${ }^{5}$ and also from the results obtained in the study.

The variability of the variables was assessed by the results of previous research from Iglinski et al. (2012), Milić (2015), Walla, Schneeberger (2008), as well as official data of the Statistical Office of Republic of Serbia, Eurostat, the Commodity exchange and the data contained in the Market Information System of the Republic of Serbia. The period of observation, depending on the data type is from 2001 to 2016.

The independent variables are the main parameters which affect the indicators chosen for the analysis of the project. In this case the value of the construction works, additional equipment, operating costs, financial costs, maintenance costs, externalities, value of produced electricity and thermal energy sold to the power grid, were taken as independent variables, because through the greater part of the project life have the greatest impact on economic indicators in the production of electrical energy of such system.

Net present value and annual profit are dependent variables, because these are indicators that allow investors to assess qualifications of a specific project through them, or to decide whether the project is economically justified. These variables directly depend on the behavior of the independent variables.

5 Agropower Austria, projects planned for Romania, Italy and Serbia 
For the assessment and projection of financial results it is analyzed value of investment works at the plant, where special attention was paid on the price of land, carried out of land works and construction works, then the installation works and installation of mechanical systems and additional equipment, which all of them make the initial costs.

Operating costs are projected on the basis of previous annual volume of the same operational costs, and include the costs of energy and fuel, labor, raw material inputs, the maintenance system cost, financial costs (interest and insurance), the costs of externalities, as well as depreciation costs which are directly linked to initial the cost of fixed assets without the land; because the land value over time is not reduced.

When the variability of the land cost was projected, the data were used for the determined land price for the following categories within the territory of Autonomous Province of Vojvodina: higher quality soils, land of lower quality, land adjacent to the village, land adjacent to the hard way, land in the area of construction, as well as the land adjacent to the land using by the tenant, using a comparison method and based on the average value per hectare for every local municipatility (Milić, 2015).

When mechanical system costs was projected, as well as cost of electrical wiring, conductors, transformers and other equipment for connecting to the grid, research was applied to the consumer price index (CPI) for industrial products from the Statistical Office of the Republic of Serbia, including: electrical equipment, motor vehicles and trailers, as well as other non-listed machines and equipment. In this part of research coefficients of variation were applied obtained by previous research (Walla, Schneeberger, 2008), concerning the variability of the capital costs value, depending on the installation type and power of plant.

For the projection value of raw materials were taken the average value, and coefficients of variation price for corn, wheat, soybean, sunflower and clover, according to data from the Market Information System of the Republic of Serbia. Also in the projection it is applied the results of research (Castillo et al. 2017) that the costs of raw material can increase by $27-31 \%$, if the biomass has lower quality, depending on the higher share of moisture and ash.

For changing the value of labor costs, variability was determined by using an index for salaries and wages per employee, from the Statistical Office of the Republic of Serbia. To determine the change in the value of construction works it is applied CPI for industrial products prices - components and materials for installation in the construction industry.

The variability of the electricity and fuel cost is determined by applying the CPI for this area.

To determine the change in financial expenses, mainly variability in interest rates was applied the index of six month Euribor, while the variability in the value of insurance costs was used the consumer price index which is applied for the insurance area. 
To determine changes in external costs the average indices of industrial products was applied for the built-in filters, while other externalities applied appropriate statistical index of value changes.

Simulation of energy system was based on projections of specific results which consists of random numbers using Microsoft Excel function NORMINV and RAND. Based on the analysis of value changes of certain parameters, as the basis for the Monte Carlo simulation, were used the normal distribution mean and standard deviation. In order to achieve the appropriate level of precision that satisfy the risk assessment of system functioning, a simulation is done through iteration of 100000 . This number of iterations has been taken in order to obtain reliable estimates of the result with confidence of 0.99 in which case the trust coefficient is 2.58 and the maximum error $2.5 \%$ (Nikolić, 2010). The required number of iterations is obtained on the following equation:

$$
n=\frac{0,9}{0,1} *\left(\frac{100}{2,5}\right)^{2} * 2,58^{2}=95.852,16
$$

\section{Results and discussion}

Assumptions of the model are:

- biomass power plant has a nominal capacity of $1 \mathrm{MW}$, - $\quad$ capacity utilization of the plant is 85\% (Glassley, 2011) and it produces electricity and heat,

- $\quad$ source of funding is $50 \%$ of own assets, and $50 \%$ is investment loan,

- $\quad$ the interest rate is $6 \%$ per annum,

- the repayment period is 10 years,

- $\quad$ the discount rate is estimated at $8 \%$,

- $\quad$ preferential purchase price (feed-in tariff) for electricity is 13.26 euro cents per $\mathrm{kWh}$ during the research period and purchase price for heat is 4 euro cents $\mathrm{kWh}$.

Decision to analyze life cycle costs for the plant of $1 \mathrm{MW}$ was created due to the easier procedures, the lack of process implementation as well as no obligation for providing certain permits, which are necessary for plants larger nominal power. Because of their lower power, small plants are more expensive than the larger (Pedraza, 2015). Therefore, the cost per unit of produced energy are smaller in in larger power plants, and also the total annual profit is more significant.

Identifying the elements of the total cost, the research uses the following equation (Kaufman, 1970) to calculate the total life cycle cost:

$$
L C C=C_{i}+C_{o}+C_{i r}+C_{d e p}+C_{m}+C_{e x}
$$


wherein:

$C_{i}$ - initial costs,

$C_{o}$ - operating costs,

$C_{i r}-$ interest and insurance costs (financial costs),

$C_{\text {dep }}-$ depreciation costs,

$C_{m}$ - maintenance cost,

$C_{e x}-$ costs of externalities.

Starting or initial costs $\left(C_{i}\right)$ are expenses incurred during the process of project development and construction, and include a series of related costs from planning, preliminary engineering, project design, technical, operational and detailed project development, licensing, personnel training to work on project, land acquisition, construction or reconstruction costs and improving existing objects, equipment purchase, but also the costs of object and equipment withdrawal that are no longer needed. This phase is of great importance as it is necessary to pay special attention to the real estimate of initial costs because of their size. The initial costs are the greatest in the method of life cycle costs of CHP plants, because of the equipment value installed in the plant. For plant of $1 \mathrm{MW}$, investments are estimated at 3,555 euros per $1 \mathrm{~kW}$.

Total annual expenditures are estimated at 0.092 euros per $\mathrm{kWh}$, or about 0.68 million euros.

Operating costs $\left(C_{o}\right)$ include raw material costs, transportation costs, energy costs, labor costs, and the costs of chemicals in everyday production cycle. At the annual level costs operating are estimated at 0.36 million euros, or 0.048 euros per $\mathrm{kWh}$.

Costs of interest and insurance $\left(C_{i r}\right)$ - financial costs, are estimated at 0.14 million euros annually, or 0.018 euros per $\mathrm{kWh}$.

Maintenance costs $\left(C_{m}\right)$, which include the cost of spare parts, service, regular and preventive system maintenance, as well as labor costs in maintenance, are estimated at 70 thousand euros annually or 0.009 euros per kWh.

Depreciation costs $\left(C_{d e p}\right)$ also are estimated to an annual level of around 70 thousand euros.

External costs include environmental protection costs (equipment, investments in research and development), and other externalities - fees, levies, taxes, fines or other economic and financial instruments directly or indirectly lead to incentive changes in the structure of the measures for economic actors behavior, by encouraging environmentally friendly behavior, which improve environmental quality (Munitlak et al., 2005). These costs are estimated at 48.5 thousand euros, or 0.007 euros per $\mathrm{kWh}$.

Total revenues directly depend on the capacity and the purchase price of the produced 
energy, and having in mind that the contract guarantees price for 12 years $^{6}$, revenues are considered stable with minimum variations related to changes in exchange rates and they are estimated to 1.2 million euros per year.

The discount rate $(d)$ represent the expected rate of return of the initial investment, i.e. it determines the amount of money an investor is willing to pay at present time with the assumed return on a projected period, taking into account the level of security from risks to achieve results. The discount rate is obtained by cumulating three levels of risk - "build up approach" (Milić, 2009). In this paper, a discount rate of 8\% is applied. Cash flows of project / investment are discounted with discount factor $(D)$ which is calculated by the following formula:

$$
D_{t}=\frac{1}{1+d^{t}}
$$

wherein $t$ represent number of investment years.

Based on previous data, the following table shows the calculation of CHP biomass plant annual results and then discounted cash flows (Table 2).

Table 1. Annual result of biomass power plant (EUR)

\begin{tabular}{|c|l|r|}
\hline I & REVENUES & $\mathbf{1 , 2 2 5 , 6 1 2}$ \\
\hline 1 & Revenue from electricity sales & 987,340 \\
\hline 2 & Revenue from the sale of thermal energy & 238,272 \\
\hline II & EXPENSES (till 10 years of repayment) & $\mathbf{6 8 3 , 8 8 2}$ \\
\hline 1 & Operating costs & 358,564 \\
\hline 2 & Maintenance costs & 70,000 \\
\hline 3 & Depreciation costs & 70,097 \\
\hline 4 & Interest and insurance costs (financial) & 136,748 \\
\hline 5 & Costs of externalities & 48,473 \\
\hline III & ANNUAL RESULT (EBIT) I-II & $\mathbf{5 4 1 , 7 3 0}$ \\
\hline & Gross margin III:I & $44.20 \%$ \\
\hline IV & ANNUAL RESULT (EBITDA) I-II + depreciation & $\mathbf{6 1 1 , 8 2 7}$ \\
\hline
\end{tabular}

Source: authors'calculations

6 Decree on incentive measures for the production of electricity from high efficient combined heat and power from renewable sources, member 3. 
Table 2. Discounted cash flow of biomass power plant (EUR)

\begin{tabular}{|c|r|r|r|r|r|}
\hline Year & $\begin{array}{c}\text { Net investment } \\
\text { inflow }\end{array}$ & \multicolumn{1}{c|}{$\begin{array}{c}\text { Discount } \\
\text { factor (D) }\end{array}$} & \multicolumn{1}{c|}{$\begin{array}{c}\text { Discounted } \\
\text { cash flow }\end{array}$} & \multicolumn{1}{c|}{$\begin{array}{c}\text { Cumulative } \\
\text { discounted } \\
\text { cash flow }\end{array}$} & NPV \\
\hline 0 & $-3,555,000$ & 1.00 & $-3,555,000$ & $-3,555,000$ & $-3,555,000$ \\
\hline 1 & 611,827 & 0.93 & 568,999 & $-2,986,001$ & $-2,986,001$ \\
\hline 2 & 611,827 & 0.86 & 526,171 & $1,095,170$ & $-2,459,830$ \\
\hline 3 & 611,827 & 0.79 & 483,343 & $1,009,514$ & $-1,976,487$ \\
\hline 4 & 611,827 & 0.74 & 452,752 & 936,095 & $-1,523,735$ \\
\hline 5 & 611,827 & 0.68 & 416,042 & 868,794 & $-1,107,693$ \\
\hline 6 & 611,827 & 0.63 & 385,451 & 801,493 & $-722,242$ \\
\hline 7 & 611,827 & 0.58 & 354,860 & 740,311 & $-367,382$ \\
\hline 8 & 611,827 & 0.54 & 330,387 & 685,247 & $-36,995$ \\
\hline 9 & 611,827 & 0.50 & 305,914 & 636,301 & 268,919 \\
\hline 10 & 611,827 & 0.46 & 281,440 & 587,354 & 550,359 \\
\hline
\end{tabular}

Source: authors'calculations

Based on the results, the investment would be repaid through a discounted cash flows in the 9 th year ( 8 years and 44 days). NPV amounts $4,105,409$ euros, IRR is $11.32 \% \mathrm{ROI}^{7}$ is $18.24 \%$, while the indicator of the profitability is $15.48 \%$.

From all the above it can be concluded, assuming 50\% of own funds and and $50 \%$ of bank loan, that the investment is justified and acceptable because:

- the net present value is greater than investment,

- internal rate of return is higher than the discount rate,

- return on investment is also above the discount rate,

- payback period of investment is in the 9th year of the investment and

- the rate of profitability is above zero.

Simulation of financial results was based on the previous values to determine deviations in individual parameters. In total annual production costs dominant category includes operating and financing costs. Operating expenses recorded a higher variability degree, primarily due to changes in raw materials consumption, the variation in raw material prices, labor costs, and the prices of fuel and energy (Table 3).

7 Return on investment (ROI)

EP 2017 (64) 2 (587-599) 
Table 3. Summary of financial results (EUR)

\begin{tabular}{|c|l|r|r|r|c|}
\hline No. & \multicolumn{1}{|c|}{ Description } & Average & \multicolumn{1}{c|}{ Structure } & $\begin{array}{c}\text { Stand. } \\
\text { Deviation }\end{array}$ & $\begin{array}{c}\text { Coefficient of } \\
\text { variation }\end{array}$ \\
\hline 1 & Construction works & $3,455,746$ & $96.96 \%$ & 66,927 & $1.94 \%$ \\
\hline 2 & Additional equipment & 108,225 & $3.04 \%$ & 3,886 & $3.59 \%$ \\
\hline A & Total initial cost 1+2 & $\mathbf{3 , 5 6 3 , 9 7 1}$ & $\mathbf{1 0 0 . 0 0 \%}$ & & \\
\hline 3 & Operating costs & 408,718 & $54.92 \%$ & 26,311 & $6.44 \%$ \\
\hline 4 & Financial costs & 139,404 & $18.73 \%$ & 1,875 & $1.35 \%$ \\
\hline 5 & Maintenance costs & 73,921 & $9.93 \%$ & 2,566 & $3.47 \%$ \\
\hline 6 & Depreciation costs & 71,438 & $9.60 \%$ & 2,325 & $3.25 \%$ \\
\hline 7 & Costs of externalities & 50,742 & $6.82 \%$ & 2,005 & $3.95 \%$ \\
\hline B & Total annual costs 3 to7 & $\mathbf{7 4 4 , 2 2 3}$ & $\mathbf{1 0 0 . 0 0 \%}$ & & \\
\hline 8 & Revenue from electricity sales & $1,023,789$ & $80.56 \%$ & 18,215 & $1.78 \%$ \\
\hline 9 & $\begin{array}{l}\text { Revenue from the sale of thermal } \\
\text { energy }\end{array}$ & 247,096 & $19.44 \%$ & 4,355 & $1.78 \%$ \\
\hline C & Total revenues 8+9 & $\mathbf{1 , 2 7 0 , 8 8 5}$ & $\mathbf{1 0 0 . 0 0 \%}$ & & \\
\hline & Annual revenue C-B & 526,733 & & 38,562 & $7.32 \%$ \\
\hline D & NPV & $\mathbf{4 , 0 5 4 , 6 5 3}$ & & 162,421 & $4.01 \%$ \\
\hline
\end{tabular}

Source: authors' calculations

Financial costs, which have a high share in total annual expenses, recorded a small coefficient of variation, which is explained by low changes in the six month Euribor rate, which directly affects the amount of interest costs. Other variations in operating costs are caused by annual price index.

The impact of changes in operating costs is significantly reflected to the change of annual profit, which shows a remarkable sensitivity of input prices changes, having in mind their high share. Annual profit has a coefficient of variation of $7.32 \%$. The coefficient of variation of net present value of $4 \%$ is acceptable, and it may be concluded that the investment will show the relative stability during 10 years of project, by given criteria. It exhibit a moderate risk degree which may be acceptable by a potential investor.

\section{Conclusion}

This paper provides a dynamic approach to assessment of total revenues and expenditures of CHP biomass plant life cycle. Variability and evaluation of indicative values obtained by the Monte Carlo method in relation to the static mathematical methods carry a certain accuracy risk of its results. Considering that this simulation method even operate with a large number of iterations, may give results that lead to incorrect decisions if the approache of interpretation is not analytical. Analytical approach of the results can respond to questions which variables have the greatest impact on calculating the NPV, or causing potential 
uncertainty, as well as how changes in certain cost categories influence the behavior of the dependent variable. These results quantify the probability of success or failure.

Results of the study provide a clear picture that revenue fluctuations most depends on the input of agricultural raw materials and variability of their value during the project life, considering the largest share of operational costs.

Annual revenues are considered to be stable, having in mind that the legislation of the Republic of Serbia guarantees the purchase price for privileged energy producers from renewable sources for a period of 12 years. Consequently, in the absence of a feed-in tariffs, such a investment would not be repaid within economically acceptable timeframe.

Investment although financed with up to a half of the funds from bank loan, indicates the relative economic stability, because changes in the financial costs due to their significant share in the total annual costs, do not show a high coefficient of variation.

Based on the stated, it can be concluded that simulation methods such as Monte Carlo method can give potential investors the significant information for investment decisions.

\section{References}

1. Andrews, D. (2009): Owning and Operating Costs of Waste and Biomass Power Plants. Claverton Energy Conference, Claverton, United Kingdom.

2. Barringer, H., P., Weber, D., P. (1996): Life Cycle Cost Tutorial. Fifth International Conference on Proces Plant Reliability. Houston, Texas, USA.

3. Castillo-Villar, K. K., Eksioglu, S., Taherkhorsand, M. (2017): Integrating biomass quality variability in stochastic supply chain modeling and optimization for largescale biofuel production. Journal of Cleaner Production, vol. 149, p. 904-918. USA.

4. Clark, V., Reed, M., Stephan, J.(2010): Using Monte Carlo Simulation for a Capital Budgeting Project. Management accounting quarterly, vol 12, No 1, p. 21, USA.

5. Glassley, W. (2011): Renewable energy and the environmental, Book. p.252

6. Hertz, David B. (1979): Risk Analysis in Capital Investment. Harvard Business Review, USA.

7. Iglinski, B., Buczkowski R., Iglinska A., Cichosz M., Piechota G., Kujawski W. (2012): Agricultural biogas plants in Poland: Investment process, economical and environmental aspects,biogas potential, Renewable and sustainable energy reviews vol. 16, p. 4890-4900, Toruń, Poland.

8. International Energy Agency. (2007): Biomass for Power Generation and CHP. p.4 Available at: $\underline{\text { ww.iea.org/publications/freepublications/publication/ }}$ essentials3.pdf

9. Kaufman, R., J. (1970): Life cycle costing: a decision-making tool for capital equipment acquision, Cost and Management. USA. 
10. Korn, R., Korn, E., Kroisandt, G. (2011): Monte Carlo methods and models in finance and insurance. Annals of Actuarial Science, vol. 5, No. 2, p 303-304. Chapman\&Hall Book, New York, USA.

11. Metropolis, N., Ulam, S. (1949): The Monte Carlo Method. Journal of the American statistical association. vol. 44, USA.

12. Milić, D. (2015): Doktorska disertacija. Metode vrednovanja poljoprivrednog zemljišta. Poljoprivredni fakultet, Novi Sad, Srbija.

13. Milić, D. (2009): Magistarsta teza. Procena vrednosti kapitala poljoprivrednog preduzeća primenom prinosne metode, Poljoprivredni fakultet, Novi Sad, Srbija.

14. Munitlak, O., Ivanović, Penezić, N. (2005): Ekonomski instrumenti u funkciji eksternih efekata. Životna sredina ka Evropi. Fakultet za preduzetni menadžment. p.228-232., Novi Sad, Srbija.

15. Pedraza, J., M. (2015): Electrical energy generation in Europe. The current situation and pespective in the use of renewable energy sources and nuclear power for regional electricity generation. Book. ISBN 978-3-319-16082-5. Vienna, Austria.

16. Princiotta, F., T. (2011): Global climate change - the technology challenge. Book. US Environmental Protection Agency, USA.

17. U.S. Department of Energy (2016): Biomass for electricity generation. Federal Energy Management Program (FEMP), USA. www.wbdg.org/resources/biomasselectricity-generation

18. Vlada Republike Srbije (2016): Uredba o podsticajnim merama za proizvodnju električne energije iz obnovljivih izvora $i$ iz visokoefikanse kombinovane proizvodnje električne i toplotne energije, Beograd, Srbija.

19. Walla, C., Schneeberger, W. (2008): The optimal size for biogas plants, Biomass and bioenergy, vol 32, p.551-557, Vienna, Austria.

20. Yu, S., Tao, J. (2008): Life cycle simulation-based economic and risk assessment of biomass-based fuel ethanol (BFE) projects in different feedstock planting areas. Energy. Science Direct, Elsevier, vol. 33, p. 375-384, Shanghai, PR China.

21. Zekić, V., Tica, N., Tomović, V., Milić D.(2014): Predviđanje ekonomskih parametara u svinjarstvu primenom simulacionih metoda. Letopis naučnih radova, vol. 38, broj I, p. 125, Novi Sad, Srbija.

22. Produktna berza, www.proberza.co.rs, december 2016.

23. Sistem tržišnih informacija Republike Srbije (STIPS), www.stips.minpolj.gov.rs/ stips/detaljni, june-december 2016.

24. Republički zavod za statistiku, www.stat.gov.rs , Saopštenja CN11, CN22, ZP14, december 2016. 


\title{
TROŠKOVI ŽIVOTNOG CIKLUSA POSTROJENJA NA BIOMASU - MONTE CARLO SIMULACIJA INVESTICIJE
}

\author{
Petrana Odavić ${ }^{8}$,Vladislav Zekic ${ }^{9}$, Dragan Milic ${ }^{10}$
}

\begin{abstract}
Apstrakt
Za izgradnju nekog sistema procena troškova životnog ciklusa smatra se kao važan faktor uspeha projekta. Stoga je cilj ovog rada da se precizno utvrde početni troškovi kao i budući operativni troškovi i troškovi održavanja CHP postrojenja na biomasu koji se stvaraju tokom određenog vremenskog perioda, a zatim putem Monte Carlo simulacije, utvrde varijacije u postavkama i mogući uticaj na rizik investicije. Rezultati pokazuju da je investicija opravdana, zbog pozitivnih ishoda neto sadašnje vrednosti (NPV), interne stopa rentabilnosti (IRR) i perioda otplate, pri čemu najveći uticaj na varijabilnost godišnje dobiti imaju operativni troškovi, koji imaju najveći koeficijent varijacije od 6,44\%, ali i najveće učešće. Varijabilnost NPV od 4\% je prihatljiva, te se investicija smatra stabilnom.
\end{abstract}

Ključne reči: troškovi životnog ciklusa, simulacija, diskontovanje.

8 Petrana Odavić, M.Sc., Savetnik za fiskalne i makroekonomske analize, Pokrajinski sekretarijat za finansije, Pokrajinska vlada, Novi Sad, Telefon: +381 603999 669, E-mail: petrana.odavic@gmail.com

9 Redovni profesor, dr Vladislav Zekić, Univerzitet u Novom Sadu, Poljoprivredni fakultet, Trg Dositeja Obradovića br. 8, Novi Sad, Telefon: +381 21485 3510, E-mail: vladislav.zekic@gmail.com

10 Vanredni profesor, dr Dragan Milić, Univerzitet u Novom Sadu, Poljoprivredni fakultet, Trg Dositeja Obradovića br. 8, Novi Sad, Telefon: +381 21485 3510, E-mail: draganzavod@gmail.com,

EP 2017 (64) 2 (587-599) 